\title{
THE ROLE OF THE PRIVATE SECURITY IN THE CRITICAL INFRASTRUCTURE PROTECTION IN SOME OF THE BALKAN STATES
}

\author{
Leta Bardzieva, MA \\ E-mail:Lbardjieva@gmail.com
}

\begin{abstract}
The paper focuses on the aspect of critical infrastructure protection by the private security segment, which has an increasingly significant role in the provision of security. The critical infrastructure system is interconnected and cannot be perceived as a separate segment of security, since it is linked with the regional and global critical infrastructure systems and standards, as well as the importance of its protection and stability in obtaining the national and international security. The private security sector has a crucial role in the protection of the critical infrastructure system, which further develops and establishes its significance and competence in this specific area. More precisely, in this paper, the scope of interest is focused on the critical infrastructure protection by the private security in the Republic of Macedonia and the Balkan countries - the Republic of Croatia and the Republic of Kosovo, as a review and comparison of specific examples.
\end{abstract}

Key words: Security, private security, regional security, critical infrastructure, protection.

\section{Introduction}

According to the EU definition of the critical infrastructure, it is defined as an asset, system or part of a system which has an essential significance and vital importance for the life, security, health, economic and social welfare of the citizens, and whose interruption or disruption, or collapse during the working process of its function would lead to incapacity of the public safety and health, commercial damage and imperilment of the national security, or a combination of them. ${ }^{38}$

${ }^{38}$ Critical Infrastructure Council Directive. http://eur-lex.europa.eu/legal-content/EN/TXT/?uri=uriserv:j0013 (посетена на 28.04.2017) 
Having in mind the contemporary trends in the field of security in the sphere of the protection of the critical infrastructure system, a conclusion could be met that the private sector operates with a large portion of the national network of critical infrastructure, the corporative management runs big organizations, to that, within the framework of that system, the calculation and risk taking, as well as ensuring security have a crucial significance. ${ }^{39}$

The focus in this paper is aimed toward examination and explication of the protection function of some of the segments of the critical infrastructure network, the regulation, the ownership and management as well as the possible threats and risks which would eventually lead toward a cessation or collapse of the production, transport and distribution of energy and resources in order to provide uninterrupted functioning of all social branches.

The methodological framework for the creation of this effort includes methods of analysis and synthesis on primary and secondary sources, internet publications from relevant institutions and bodies, announcements and decisions from competitive organs and literature for the same realm and a comparative display of the gathered information and data.

\section{Critical infrastructure networks - identification and protection}

Designating the objects and capacities of the critical infrastructure and their protection, according to the standpoints reflected in the official formulations of the European Union, and whose part the Western Balkan strives to be, counterpoise an obligation and responsibility of the national states. ${ }^{40}$ Each country on its authentic way settles and prescribes the legal framework with which the function protection of the critical information systems will be achieved, in order to provide an uninterrupted and constant flow of resources and energy for the functioning of the social and the economic system.

As an explicative review the regulations for identification and protection of the critical infrastructure networks will be displayed, regarding the efforts and steps of some of the countries in the region. In some of them, the concept is in an initial phase, and in some countries the critical infrastructure does not exist as an official term used to

39 International CEP Handbook. Civil Emergency Planning in the NATO/EAPC Countries. Swedish Civil Contingencies Agency. https://www.msb.se/RibData/Filer/pdf/24677.pdf (посетена на 16.04.2017)

40 Правна рамка за обезбедување на критичната инфраструктура - со осврт на обезбедувањето на критичната инфраструктура во Република Македонија. Комора на Република Македонија за приватно обезбедување, Скопје, 2016. 


\section{Security}

define the specific system for production, transport and use of energy. ${ }^{41}$ The threats and the risks for the survival and functioning of the critical information systems could have internal or/and external origin. ${ }^{42}$ Internal threats and/or risks include accidents during the working process itself, natural disasters, as well as anthropogenic accidents, theft, sabotage, industrial espionage etc. The threats and risks with an external genesis include terrorist attacks, diversions, natural disasters, invasion, etc.

Picture 11: Risk and threats analysis on the critical infrastrucutre systems

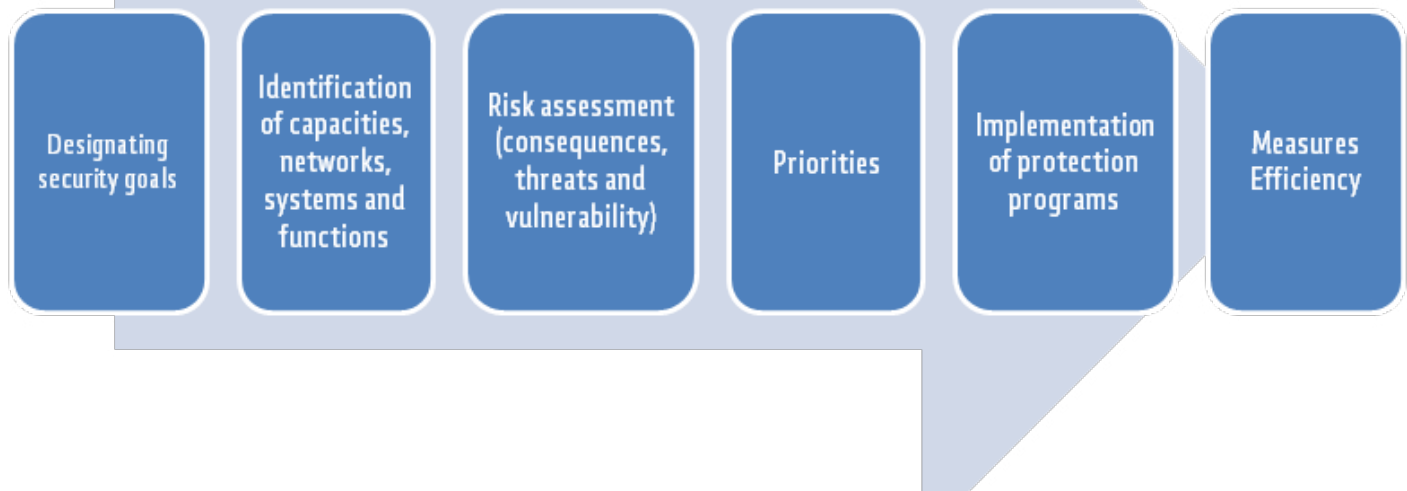

So far, there are numerous legal and institutional mechanisms designated as a response for the provision of the optimal level of security for the networks of the national, the regional, the European and the global critical infrastructure. According to the recommendations from the Strategy for the development of the private security in the Republic of Macedonia from 2016, among other forms of management with the critical infrastructure management, as one of the most efficient and most adequate in this sector are public - private partnerships, the improvement of the professionalization and standardization, designation and identification of a formal list of critical infrastructure assets on a national and international level, as well as increasing the ways and communications for cooperation on a regional level etc. ${ }^{43}$

\footnotetext{
41 Република Црна Гора формално не го користи терминот критична инфраструктура и нема развиена политичка рамка за заштита на овој сектор. Bigović, M., Rakočević, A.: Challenges in Defining Critical Infrastructure in Montenegro, 2015.

42 Common Threats and Vulnerabilities of Critical Infrastructures. International Journal of Control and Automation. https://pdfs.semanticscholar.org/7098/a29a404f8561c7f3c66801b6elf36f88b7b7.pdf (посетена на 29.04.2017)

43 Бакрески, 0., Милошевиќ, М.: Современи безбедносни системи - Компаративна анализа на земјите од Југоисточна Европа. Аутопринт Т. А., Скопје, 2010.
} 
Creating public - private partnerships becomes an increasing priority, in order to make mutual efforts in achieving the optimal level of security on the production, transport and distribution of energy through the critical infrastructure network. ${ }^{44}$ Combined ownerships and authorizations when appropriately regulated and controlled contribute flexibility when dealing with the threats and risks to the security on a national, local and regional level. ${ }^{45}$ Also, standardization in the sector of critical infrastructure protection and the systems within the frameworks of the European critical infrastructure and other trans- national energy and resources networks counterpoises a mechanism which would enable increase of the level of cooperation and inter- operability among the countries in the Balkans. ${ }^{46}$

\section{A comparative display on the legal framework and activities in the identification and the protection of the critical infrastructure systems in the Republic of Macedonia, the Republic of Croatia and the Republic of Kosovo}

Identification and regulation of the national critical infrastructure network in the Republic of Macedonia

According to the analysis of the current situation, from the aspect of legal regulation, the critical infrastructure remains a new area, respectfully, a matter which is yet to be defined, identified and determine its protection. In the Republic of Macedonia there still is no formally designated list of critical infrastructure, but certain important leaps have been made in the creation of a regulated ambience and a clearly designated framework for diligence, activities, subjects whose responsibility and authorization is protection of the national critical infrastructure. ${ }^{47}$ In the analysis of the situation in the Republic of Macedonia from the legal solutions aspect, the accent will be put on the Law for energetic, Law for private security and the Decision for designating legal entities which are obliged to have security for persons and property for own purposes, the Strategy for development of the private security, the Strategy for energetic development of the Republic of Macedonia and the cooperation initiative Western Balkan 6.

44 http://www.securitycouncilreport.org/monthly-forecast/2017-02/counter-terrorism_protection_of_critical_infrastructure.php (посетена на 16.04.2017)

45 Dani Kriznog Upravljavanja. Crisis Management Days. 8-ma Međunarodna Znanstveno- Stručna Konferencija. University of Applied Sciences Velika Gorica, May 2015. http://dku.hr/wp-content/ uploads/2016/09/DKU-2015-VVG.pdf (посетена на 29.03.2017)

${ }^{46}$ Dani Kriznog Upravljavanja. Zbornik Sažetaka. http://portal.research.lu.se/portal/ files/5709251/5470097.pdf (посетена на 29.03.2017)

47 Slaveski, S., Hadji-Janev, M.: Corporate Security and Critical Infrastructure Protection in the Republic of Macedonia: Perspectives and Challenges. Security Dialogues http://sd.fzf.ukim.edu. mk/4/gegag?start=1 (посетена на 29.03.2017) 
Having in mind that the introduction of the market economy in the transition countries such as the case with the Western Balkan countries, had led to the spread of private ownership, increase of the economic and trade exchange, foreign investments increase etc, which as tendencies and occurrences had drawn a series of measures which need to be undertaken in order for the protection of the companies, their activities and employees as well as to enable protection of the economic and the political order, the environment while the conduction of the activities of the companies and finally, protecting the critical infrastructure capacities by private companies offering security services. ${ }^{48}$

The energy sector and the security sector, are interrelated and they are both part of the integral national security. Their efficiency, effectiveness and transparency has an essential significance for the maintenance of the energy, and internal/regional security. ${ }^{49}$

In the Strategy for energy development of the Republic of Macedonia till 2030 the energy security is defined as regularly satisfying regarding the demands, in sustainable natural conditions and under prices which do not slow down the economic growth and do not disorganize the living standard of the citizens..$^{50}$ In order to achieve and maintain energy security, it is necessary to utilize the domestic energy potential, and among the first are mentioned the renewable energy sources, the diversification of the energy sources, a stabile infrastructure network for energy export and import and energy efficiency measures. The listed parameters necessary to achieve energy stability have to be additionally fueled with political will and institutional capacities, expressed through the strategic plans for the energy sector and through implementation of several modes of measures for public investments realizations, tax exceptions, subventions, grants, investments in energy efficiency reforms, awareness raising campaigns, regional and international cooperation in this sphere etc. ${ }^{51}$

\footnotetext{
48 Бакрески, Оливер et al. Корпорациски Безбедносен систем. Комора на Република Македонија за обезбедување лица и имот. Скопје, 2012.

49 Управување со секторите енергетика и безбедност во Македонија - како да се подобри нивната ефикасност? Analytica Policy Report.

50 Stojilovska, A.: The Role of the Private Sector in Achieving Energy Security in the Western Balkans: Macedonia as a Case Study. Политичка мисла - Стратегии за регионална безбедност. 6p.36, 2011. http://www.kas.de/wf/doc/kas_29730-1522-2-30.pdf?111214082858 (посетена на 08.04.2017)

${ }^{51}$ Агенција за енергетика на Република Македонија. Стратешки документи. Прв акционен план за ЕЕ на РМ до 2018 година.
} 
The Republic of Macedonia is a part of the Energy Community West Balkan $6^{52}$ - initiative called "energy measures" signed by Serbia, Macedonia, Albania, Bosnia and Herzegovina, Montenegro and Kosovo on the Wien Summit in 2015 consisted by initiatives and measures for electricity trade, integrated markets, regional balance and regional capacity allocation, as well as overcoming the existing regulatory and legal barriers makes efforts for regional integration and market stabilization for electric energy supply, which counterpoises a fundamental segment of the critical infrastructure system. ${ }^{53}$

With the Law for energy from 2011 the Republic of Macedonia arranges, among other issues, the energy activities and the regulation of the energy activities, the goals of the energy policy and the methods for its realization, the building of the energy capacities, according to Article 1; Article 2 from this Law specifies the goals with which a secure, safe and quality energy supply for the consumers should be provided, as well as the creation of an efficient, competitive and financially sustainable energy sector, stimulation of concurrency on the energy markets, with the respect for the principles of non- discrimination, transparency and objectivity, integration of the Macedonian energy market in the regional and the international energy markets in accordance with the international ratified agreements, increase of the energy efficiency and instigation of the use of renewable sources of energy, as well as preservation of the environment from the negative influences during the execution of some activities in the energy sector..$^{54}$

Article 3 defines the terms and their meaning in the same Law, in which Article 1 accounts for the meaning of the security - the ability to provide protection for the health and the lives of people, protection of the environment and the assets by undertaking technical and other kinds of security measures during the production, the transport and the distribution of energy and resources.

\footnotetext{
${ }^{52}$ Energy Community Wetsern Balkan 6: https://www.energy-community.org/portal/page/ portal/ENC_HOME/AREAS_OF_WORK/WB6 (посетена на 16.04.2017)

${ }^{53}$ Western Balkans 6 Ministerial Meeting. Ministers of Energy and Ministers of Foreign Affairs. Joint Statement of the Ministers of Energy. Skopje, February 2017. https://www.energy-community.org/portal/page/portal/ENC_HOME/DOCS/4538397/482CA611C7BA6023E053C92FA8C0E7B9.pdf (посетена на 16.04.2017)

${ }^{54}$ Службен весник на Република Македонија 6р. 07-610/1. Указ за прогласување на Законот за енергетика http://www.erc.org.mk/odluki/SLUZ.VES.BR.16-10.02.2011-ZAKON\%20ZA\%20 ENERGETIKA.pdf
} 


\section{Securiaty}

The main provisions in Article 3 from the Law for energy of the Republic of Macedonia define the activities in the energy sector:

1. Production, transport and distribution of electrical energy,

2. Coal production and manufacturing,

3. Petroleum and petroleum derivate production, processing and transport,

4. Natural gas production, transport and distribution,

5. Heat and geothermal energy production, transport and distribution,

6 . Production of other kinds of energy.

These activities could be performed by domestic and foreign legal entities and individuals under conditions designated by the same Law. Article 12 from the Law refers to the prescribed standards, technical norms and the norms for energy production quality, delivery and utilization by the subjects, machines and plants for production, transmission, distribution and transport and utilization of the energy, on which the accent is put on the protection of the people, material goods, environment and nature.

The Law for private security is substantially guided by the definitions from the Law for protection of persons and property, and Chapter 5 arranges the topic for Mandatory private security. It is important to remark that, beside the Law for private security ${ }^{55}$, Chapter 6 from the Low for defense of the Republic of Macedonia, defines the subjects which have a special significance for the defense - public enterprises and companies from the energy sector, traffic, communications, communal activities, constructions whose responsibility is giving priority to the demands of the defense, the Army, the organs of state administration etc. To that, the Government of the Republic of Macedonia in 2013, with the Decision for designation of legal entities obliged to have private security, consequentially recognizes the infrastructure which needs to be a subject of protection. With this decision, the Government of the Republic of Macedonia defines three types of legal entities a) the first group legal entities conduct activities related to radioactive materials or other materials harmful for people and environment manipulation b) the second group of legal entities which performs activities related with handling items and objects with special cultural- historical significance and c) the third group of legal entities which are obligated to have private security based on a special treatment, respectfully the same are a matter of interest for the security and the defense of the Republic of Macedonia.

${ }_{55}$ Службен весник на РМ. Бр. 166/2012, 164/2013, 148/2015, 193/2015, 55/2016. 
Table 2: Legal entities prescribed with the Decision for designation of legal entities obliged to have private security

\begin{tabular}{|l|l|l|}
\hline 1. & $\begin{array}{l}\text { Legal entities whose activity is related with handling radioactive materials } \\
\text { or other material hazardous for people and environment }\end{array}$ & 468 \\
\hline & $\begin{array}{l}\text { Legal entities registered for conducting activities in accordance with the } \\
\text { Law for protection from ionization and radiation safety }\end{array}$ & 83 \\
\hline & $\begin{array}{l}\text { Private entities registered for wholesale production and trade of medica- } \\
\text { ments and medical equipment }\end{array}$ & 273 \\
\hline & Health institutions for secondary and tertiary hospital health protection & 70 \\
\hline 2. & $\begin{array}{l}\text { Legal entities for production and trade with flammable liquids and combus- } \\
\text { tible gases and legal entities registered for hazardous materials transport }\end{array}$ & 42 \\
\hline with special cultural and historical value & $\begin{array}{l}\text { Private security for legal entities in the interest of the security and defense } \\
\text { of the Republic of Macedonia }\end{array}$ & 523 \\
\hline & Legal entities registered for performing activities in the energy sector & 171 \\
\hline $\begin{array}{l}\text { Legal entities registered for performing activities in the water supply sector } \\
\text { for technical and potable water }\end{array}$ & 5 \\
\hline & $\begin{array}{l}\text { Legal entities registered for performing activities for protection and man- } \\
\text { agement with multipurpose areas, protection and promotion of the natural } \\
\text { environment and natural heritage in protected areas and outside the pro- } \\
\text { tected areas }\end{array}$ & 246 \\
\hline & $\begin{array}{l}\text { Public Enterprise Macedonian Radio Television and other legal entities reg- } \\
\text { istered for performing activities with public interest (electronic and printed } \\
\text { media) }\end{array}$ & 82 \\
\hline $\begin{array}{l}\text { National Bank of the Republic of Macedonia and legal entities registered for } \\
\text { performing banking matters }\end{array}$ & 19 \\
\hline
\end{tabular}

\section{Protection of the critical infrastructure of the Republic of Croatia}

The Republic of Croatia is a country from the region which has done the most steps regarding the legal regulation of the critical infrastructure. The critical infrastructure is mentioned in the 2008 Strategy for countering terrorism, where it is approached from the aspect of protection from terrorist attacks, as well as the National Strategy and Action plan for prevention of the spread of weapon of mass destruction, where as a special goal is induced the protection of the critical infrastructure. ${ }^{56}$ The country began ${ }^{56}$ Čaleta, D., Radosevic, S.: Comprehensive Approach as "Sine Qua Non" for Critical Infrastructure Protection. Belgrade, 2015. 


\section{Security}

with identification, designation and protection of the national and the European critical infrastructure, and several years in rearwards, the importance of the critical infrastructure and its protection is emphasized in several documents. ${ }^{57}$

In 2013, an evaluation was conducted for the vulnerability from large scale natural and technical- technological accidents and disasters, where the critical infrastructure system is viewed from a macro aspect; the protection and rescue plan on the territory of the Republic of Croatia from 2010 treats critical infrastructure from the aspect of a display and review of the responsibilities and cooperation between the institutions in charge for enforcing the protection and rescue measures. ${ }^{58}$ In 2013, the Republic of Croatia brought a Law for critical infrastructure as a result of the approximation with the EU legislature and the near drawing date for EU entrance. With the full membership in the EU, the private security companies in large scale and more expressive have taken the work related with the protection of the critical infrastructure, securing airports, as well as other activities with significance for the security of the persons and property, which is in the favor of the necessary level of competence, quality, responsibility which are set upon the security agencies and the conduct of their activities. ${ }^{59}$

Слика 2: Assessment and analysis of the security condition of the critical infrastructure

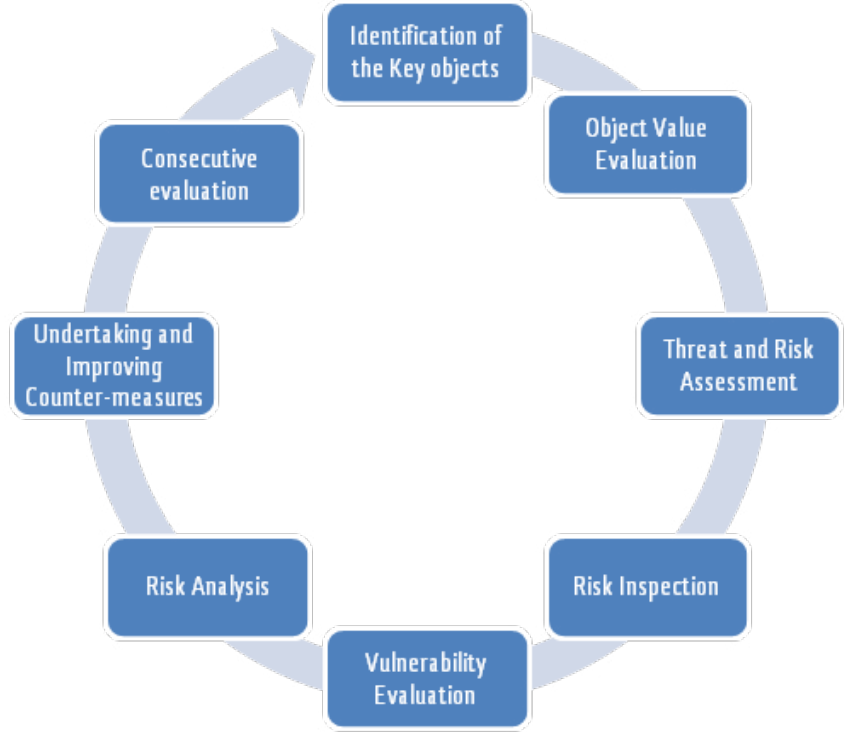

\footnotetext{
57 Što je doista Kritična Infrastruktura? http://zastita.info/hr/novosti/sto-je-doista-kriticna-infrastruktura,16065.html (посетена на 10.04.2017)

${ }^{58}$ Hrvatski Ceh Zaštitara. Strukovna Zaštitarska Komora: http://hcz.hr/ (посетена на 10.04.2017)

${ }^{59}$ Croatia's Accession to the European Union. http://europa.eu/rapid/press-release_MEM0-13629_en.htm (посетена на 14.04.2017)
} 
The Law for private protection in the Republic of Croatia designated the code of conduct for the protection of persons and property activity and the sphere in which the state designates the realm of the private protection, the regulation of the conduct, the tasks and working methods, as well as the oversight of the conduct. ${ }^{60}$ The legal entities and companies which offer private security services must not apply operative methods and means which by regulation are used by the Ministry of internal affairs in the Republic of Croatia. Article 2 from this Law defines the terms and their meaning, whereas article 11 refers to the critical infrastructure, defined in the Law of the Republic of Croatia as an activity, network, services and goods with material or informatics technology whose destruction or defect would lead to significant threat for the health and the security of the citizens, or for the unimpeded function of the state authorities.

Article 3 from the Law for private security in the Republic of Croatia arranges the manner of the conduct of the private security activity, respectfully, if a certain legal entity or company has a need for protection for its employees and assets, has to hire a legal entity or a company authorized for performing such activities, or has to establish an internal security service on its own. Article 4 refers to the subjects which perform the private security activity. Namely, they have to be registered in the authorized mercantile court, except the secret companies. According to the Croatian Law, the private protection activity could be performed by legal entities and companies that deal with technical protection, while physical protection is performed for personal needs solely, in accordance with the definitions from this Law for internal guard service. In accordance with the dispositions from this Law, the private protection activity could be performed by legal entities and companies from the European Union, as well as the Agreement for European Economic Area signatory countries. ${ }^{61}$

\footnotetext{
${ }^{60}$ Zakon HR. Закон за приватна заштита. https://www.zakon.hr/z/291/Zakon-o-privatnojza\%C5\%Altiti (посетена на 10.04.2017)

${ }_{61}$ ЕЕП -основан со цел земјите Исланд, Лихтенштајн и Норвешка и земјите од ЕФТА да учествуваат на единствениот пазар на ЕУ.
} 


\section{Critical Infrastructure Protection in the Republic of Kosovo}

According to the Law for critical infrastructure of the Republic of Kosovo, brought by the Assembly of Kosovo, in accordance with the EU Directive 2008/114/EC, the purpose for the bringing of this draft bill is the protection of the national and the European critical infrastructure systems and incident prevention and minimizing the potential damage on the critical infrastructure systems. ${ }^{62}$ This law enables directions for the identification of the critical infrastructure systems with national and European character; it designates the criteria, as well as the directions for its management, including risk assessments and analysis. Also, it is consisted by plans for the owners/operators of the critical information systems, their roles and responsibilities, as well as sanctions in case it is not acted in accordance with the legal regulations.

As one of the strategic goals of the Republic of Kosovo - gaining full membership in the EU, regional cooperation and good conjuncture is prescribed, which is, among others, one of the preconditions imposed for this neighboring country in order to fulfill the membership criteria. The National strategy and Action plan 2016-2019 of the Republic of Kosovo, define critical infrastructure as objects or institutions with great significance for the public wellbeing, whose failure or damage would lead to significant deficiency in the supply, a threat for the public safety or other dramatic consequences. The critical information infrastructure in the Republic of Kosovo in the National strategy is defined as systems which are critical infrastructure themselves, or as necessary for the functioning of the critical infrastructure (telecommunications, internet, satellites, etc.)

As one of the priorities for building security networks of the critical infrastructure and appropriate mechanisms and measures for their protection, in order to provide an unimpeded functioning of all social activities, the identification and the assessment of the critical infrastructure of Kosovo are identified, under previously established criteria. ${ }^{63}$

\footnotetext{
62 Влада на Република Косово. Министерство за внатрешни работи, Нацрт- закон за критична инфраструктура: https://www.google.com/url?sa=t\&rct=j\&q=\&esrc=s\&source=web\&cd=3\&cad =rja\&uact=8\&ved=0ahUKEwjOtuOumMnTAhWIHpoKHTasBigQFgg2MAI\&url=http\%3A\%2F\%2Fko nsultimet.rks-gov.net\%2FStorage\%2FConsultations\%2F08-43-18-21032017\%2FPROJEKTLIGJI\%2 520PER\%2520INFRASTRUKTUREN\%2520KRITIKE_2017.doc\&usg=AFQjCNEzCLzPebgMfw3WRhS 0dShJDpmYyw\&sig2=0-4agVBHKdMLOm_7P16i8g (посетена на 28.04.2017)

${ }^{63}$ Baftiu, N.: Cyber Security in Kosovo. European Journal of Economics, Law and Social Sciences, Vol. 1, No. 1. IIPCCL, Publishing, Graz- Austria, January 2017. http://iipccl.org/wp-content/uploads/2017/01/160-167.pdf (посетена на 29.04.2017)
} 

followed:

During the identification of the critical infrastructure, these steps should be

- Designation of the objects which will be treated (audio communications, data, their storage and procession)

- Identification of the infrastructure which is technically necessary for the functioning of these services

- Establishing objective criteria for the necessary level of protection for every infrastructure element, infrastructure categorization and appliance of criteria, such as the number of users which might be affected, level of vulnerability

- Investigating scenarios for development criteria which will examine the consequences of the given infrastructure as regular activities.

As one of the indispensable and essential elements for critical infrastructure protection is claimed to be the building of capacities and development of institutional mechanisms, which can be achieved primarily through cooperation between the various subjects involved in this sphere. The coordination of the relevant authorized instances is also needed, as well as taking special protection measures, among which are management expertise and knowledge for the matter, continuous simulations and training on a local, regional and international level which would lead to an increased inter- operability and experience exchange and practice, as well as enabling proper education and training for the citizens of Kosovo and involved parties.

Technical infrastructure, human resources and research and development are also listed in the mechanisms and measures which are necessary for building functional capacities for critical infrastructure protection. ${ }^{64}$

As one of the concrete measures induced is the information exchange, especially with the sectors:

- Internet providers

- Banking sector

- Energy sector

- Water supply

- Transport (air and land)

- Academic sector.

The Republic of Kosovo also is committed to take active participation in bilateral and multilateral agreements with key allies as well as other countries in order to strengthen the security of the cyber space and the critical infrastructure. Further, participation in regional forums, with the accent of building regional capacities, as well as

${ }^{64}$ Собрание на Република Косово. http://www.kuvendikosoves.org/?cid=2,122 (посетена на 16.04.2017) 


\section{Security}

membership in international organizations which support best practices and building a global coordinated approach in the combat against threats on the critical infrastructure security. 65

Regarding the management with the national critical infrastructure network and the regional cooperation, the Republic of Kosovo is part of the Western Balkan 6 initiative and the Berlin process. ${ }^{66}$

According the European recommendations, the energy sector in particular, the Republic of Kosovo its efforts should direct toward price regulation, introduce a compatible Law on energy, finalize the negotiations with the Republic of Albania for energy exchange, as well as to finalize the technical procedures for the creation of a stabile and balanced market.

In relation to the protection of the critical infrastructure networks, the Republic of Kosovo has already made few steps when it comes to critical infrastructure protection, with the accent set on the cyber community and the protection of the critical information infrastructure. ${ }^{67}$

The National strategy for cyber security 2016-2019 has the following main goals:

- Protection of the critical information infrastructure

- Capacity building (legal, human and infrastructure)

- Public- private partnerships

- Incident response

- International cooperation. ${ }^{68}$

\section{Conclusion}

The efficient protection of the critical infrastructure prescribes mobilization of several institutions, state bodies and private entities, as well as creation of a new legal framework on a national level and adoption of international agreements and resolutions with which the protection of the critical infrastructure activity will be defined and the cooperation in the realm of production, transport and distribution of energy and resources security which counterpoises a priority activity of the authorized instances.

\footnotetext{
${ }^{65}$ Republic of Kosovo National Strategy Against Terrorism 2012-2017. https://www.mpb-ks.org/ repository/docs/Strategy_for_Counter_Terrorism_2012-2017_eng.pdf (посетена на 29.04.2017) ${ }^{66}$ Kosovo Report. European Commission, Brussels, 2016. Commission Staff Working Document. ${ }^{67} \mathrm{http}$ // www.kosovapress.com/en/news/mia-part-of-critical-infrastructure-protection-in-eu-conference-106134/ (посетена на 11.04.2017)

${ }^{68}$ National Cyber Security Strategy and Action Plan 2016-2019https://www.sbs.ox.ac.uk/cybersecurity-capacity/system/files/National_Cyber_Security_Strategy_and_Action_Plan_2016-2019_0. pdf
} 
Having in mind the dynamic occurrences and the threats whose genesis varies, and their intensity and consequences have a destructive meaning for the functioning and the survival of the political and the economic order of the countries, it is necessary to engage and utilize all the means at disposal on a national and on a regional level in order to provide the optimal level of security of the critical information systems.

The necessary mechanisms and methods for cooperation on a multilateral and bilateral plan which are imposed as an imperative for the achievement of the optimal level of critical infrastructure protection must not be avoided or neglected, and the promotion of standardized and unified responses against the threats over the critical infrastructure systems should be a supplement on the already existing norms and regulations which arrange this matter.

Each country from the region is on its individual path regarding the regulation and the designation of this significant security, political and economic issue whose importance goes beyond the national borders.

This paper had the purpose to display the legal regulations and prescriptions with which the activity critical infrastructure protection is organized in the Republic of Macedonia, the Republic of Croatia and the Republic of Kosovo. Each of these countries has its own specifics, challenges which have to be overcome and processes that need to be smoothen up. 


\section{Security}

\section{Bibliography:}

1. Bourne, M. (2014) Understanding Security. London: Palgrave MacMillan.

2. Čaleta, D., Radosevic, S. (2015), Comprehensive Approach as "Sine Qua Non" for Critical Infrastructure Protection, Belgrade, 2015.

3. Gariup, M. (2013), European Security Culture: Language, Theory, Policy. Ashgate.

4. Högselius, P, et al. (2013), The Making of Europe's Critical Infrastructure: Common Connections and Shared Vulnerabilities. London: Palgrave MacMillan.

5. National Strategies and Structures for Infrastructure Protection. Report to the President's Commission on Critical Infrastructure Protection. (1997)

6. Perdikaris, J. (2014), Physical Security and Environmental Protection, NY: CRC Press, Taylor \& Francis Group.

7. Rice, M., Shenoi, S.: Critical Infrastructure Protection X. Springer, 2015.

8. Бакрески, О., Триван, Д., Митевски С. (2012), Корпорациски безбедносен систем, Скопје:Комора на Република Македонија за обезбедување лица и имот.

9. Правна рамка за обезбедување на критичната инфраструктура- со осврт на обезбедувањето на критичната инфраструктура во Република Македонија. Комора на Република Македонија за приватно обезбедување. Скопје, 2016.

10. Приватната безбедност во 21 век: Искуства и предизвици. Комора на Република Македонија за приватно обезбедување. Скопје, 2016. 